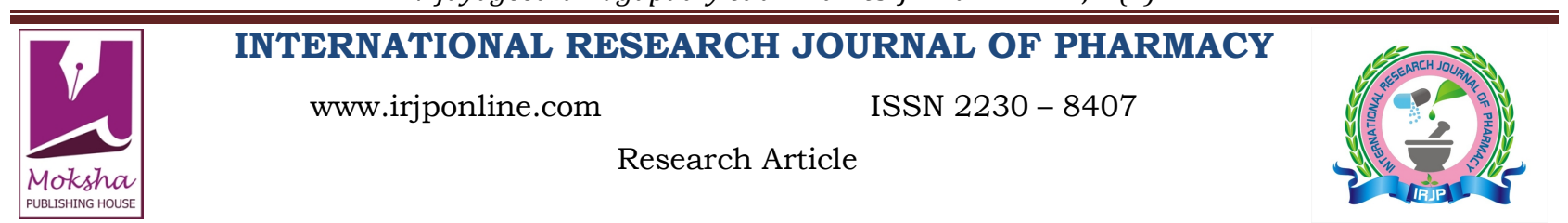

\title{
SIMULTANEOUS SPECTROPHOTOMETRIC DETERMINATION OF RABEPRAZOLE SODIUM AND DOMPERIDONE MALEATE IN CAPSULES BY CHEMOMETRIC METHODS
}

\author{
Vijayageetha Ragupathy*1, Shantha $\operatorname{Arcot}^{2}$ \\ ${ }^{1}$ Department of Pharmaceutical Analysis, Faculty of Pharmacy, C.L Baid Metha College of Pharmacy, Chennai, Tamil Nadu, \\ India \\ ${ }^{2}$ HOD, Department of Pharmaceutical Analysis, C.L Baid Metha College of Pharmacy, Chennai, Tamil Nadu, India \\ *Corresponding Author Email: venista7@gmail.com
}

Article Received on: 18/03/13 Revised on: 01/04/13 Approved for publication: 19/05/13

DOI: $10.7897 / 2230-8407.04616$

IRJP is an official publication of Moksha Publishing House. Website: www.mokshaph.com

(C) All rights reserved.

\section{ABSTRACT}

Simultaneous spectrophotometric determination of Rabeprazole sodium and Domperidone maleate was performed by partial least-squares (PLS) and principal component regression (PCR) methods do not require any priori graphical treatment of the overlapping spectra of two drugs in the mixture. The absorbance values in the UV-Vis spectra were measured for the 89 wavelength points (from 221-309) in the spectral region 200-400nm considering the intervals of $1 \mathrm{~nm}$. The calibration range was found to be $4-20 \mu \mathrm{g} / \mathrm{ml}$ for Rabeprazole sodium, $6-30 \mu \mathrm{g} / \mathrm{ml}$ for Domperidone maleate with a correlation coefficient of 0.9999 (PLS), 0.9999 (PCR) for Rabeprazole sodium and 0.9999 (PLS), 0.9999 (PCR) for Domperidone maleate. The validation of the multivariate methods was realized by analyzing the synthetic mixtures of Rabeprazole sodium and Domperidone maleate. The numerical calculations were performed with the 'Unscrambler $10.1 \mathrm{X}$ ' software. The chemometrics analysis methods were satisfactorily applied to the simultaneous determination of Rabeprazole sodium and Domperidone maleate in the pharmaceutical formulation.

Keywords: Domperidone maleate, chemometrics, Rabeprazole sodium, spectrophotometry, partial least square, principal component regression.

\section{INTRODUCTION}

Rabeprazole sodium (RABE) is proton pump inhibitor and is not official in any of the Pharmacopoeias and is chemically 2-(\{[4-(-3-mehotxypropoxy)-3- methyl-2- pyridyl] methyl $\}$ sulfinyl)-1H-benzimidazole sodium. ${ }^{1}$ Domperidone maleate (DOM) is peripheral dopamine antagonist. It is official in British Pharmacopoeia and European Pharmacopoeia. Chemically it is 5-chloro-1-[1-[3-(2-oxo-2, 3-dihydro- $1 \mathrm{H}$ benzimidazol-1-yl) propyl]-piperidin-4-yl]-1, 3-dihydro-2H benzimidazol-2-one ${ }^{2-4}$. Literature survey reveals Rabeprazole sodium and Domperidone maleate were simultaneously estimated by UV spectrophotometric methods ${ }^{5-9}$. HPLC ${ }^{10-12}$ and HPTLC ${ }^{13-15}$. No chemometric method is reported for the simultaneous determination of Rabeprazole sodium and Domperidone maleate in bulk and capsule dosage forms. The present article discusses the attempts made to develop simple, sensitive, reproducible and economical chemometric methods for simultaneous determination of these drugs in dosage forms. In recent years, multivariate calibrations such as classical least-squares (CLS), inverse least-squares (ILS), principal component regression (PCR) and partial leastsquares (PLS) are started to apply to the analysis of the analytical data obtained in all the instrumentations ${ }^{16-17}$. It is probably the area within chemometrics which has attracted the most interest so far. The approach is useful in the simultaneous spectrophotometric determination of two or more components in a pharmaceutical formulation with overlapping spectra. These are extensively used in quantitative spectral analysis to get selective information from unselective data. These methods have been found to be the method of choice for complex mixtures. The advantage of multi-component analysis using multivariate calibration is the speed of the determination of components in a mixture, avoiding a preliminary separation step. The control analysis on pharmaceutical formulations using the multivariate calibration methods has been proved to be a valid alternative to HPLC. The objective of this paper is to investigate the ability of PLS and PCR models to quantify the binary mixture of RABE and DOM with overlapped UV spectra and to apply the optimised models in pharmaceutical formulations. The proposed methods are simple and accurate, resulted in a significant reduction in analysis time and proved to be suitable for routine determination of the two components of the standard mixture.

\section{MATERIALS AND METHODS}

Instruments and software

Digitized UV/VIS absorbency spectra were collected using a UV-visible spectrometer 2300Techcomp with $1 \mathrm{~cm}$ quartz cells. The data acquisition was made with UV solutions software at a scan rate of $1000 \mathrm{~nm}$ min-1 and the slit width of $2 \mathrm{~nm}$. The UV spectra of mixtures were recorded over the wavelength $221-309 \mathrm{~nm}$ with one data point per $\mathrm{nm}$. All spectral measurements were performed using blank solution as a reference. Partial least squares regression, and principal component regression were used for chemometric analysis of data. For all calculations Unscrambler for windows (Version 10.1 X) was used.

\section{Pharmaceutical tablet formulations}

A commercial pharmaceutical formulation (RAPEED - D) capsule containing $20 \mathrm{mg}$ of RABE and $30 \mathrm{mg}$ of DOM was analyzed by the proposed chemometric methods.

\section{Preparation of stock solutions}

Stock solutions were prepared by dissolving 40mg of Rabeprazole sodium and 60mg Domperidone maleate in $100 \mathrm{ml}$ volumetric flasks and the volume was made up with methanol. The training set containing $4-20 \mu \mathrm{g} / \mathrm{ml}$ Rabeprazole sodium and $6-30 \mu \mathrm{g} / \mathrm{ml}$ Domperidone maleate working standard solutions were prepared by diluting the stock solutions for each drug according to its linear calibration range. 
Vijayageetha Ragupathy et al. Int. Res. J. Pharm. 2013, 4 (6)

Table 1: Composition of Calibration (Training Set) Set For PLS and PCR Methods

\begin{tabular}{|c|c|c|c|c|c|}
\hline \multicolumn{3}{|c|}{ Rabeprazole sodium } & \multicolumn{3}{|c|}{ Domperidone maleate } \\
\hline \multirow[t]{2}{*}{ Reference $\mu \mathrm{g} / \mathrm{ml}$} & \multicolumn{2}{|c|}{ Predicted $\mu \mathrm{g} / \mathrm{ml}$} & \multirow[t]{2}{*}{ Reference $\mu \mathrm{g} / \mathrm{ml}$} & \multicolumn{2}{|c|}{ Predicted $\mu \mathrm{g} / \mathrm{ml}$} \\
\hline & PLS & PCR & & PLS & PCR \\
\hline 4.00 & 4.03 & 4.00 & 6.00 & 6.09 & 6.01 \\
\hline 4.00 & 4.03 & 4.00 & 12.00 & 12.07 & 12.01 \\
\hline 4.00 & 4.02 & 4.00 & 18.00 & 18.00 & 17.95 \\
\hline 4.00 & 4.01 & 4.00 & 24.00 & 24.06 & 24.03 \\
\hline 4.00 & 4.00 & 4.00 & 30.00 & 30.01 & 30.00 \\
\hline 8.00 & 8.03 & 8.01 & 6.00 & 6.07 & 6.01 \\
\hline 8.00 & 8.03 & 8.01 & 12.00 & 12.06 & 12.01 \\
\hline 8.00 & 8.02 & 8.01 & 18.00 & 17.98 & 17.95 \\
\hline 8.00 & 8.01 & 8.01 & 24.00 & 24.05 & 24.03 \\
\hline 8.00 & 8.00 & 8.01 & 30.00 & 29.99 & 30.00 \\
\hline 12.00 & 12.04 & 12.02 & 6.00 & 6.05 & 6.01 \\
\hline 12.00 & 12.04 & 12.02 & 12.00 & 12.04 & 12.01 \\
\hline 12.00 & 12.03 & 12.02 & 18.00 & 17.96 & 17.95 \\
\hline 12.00 & 12.02 & 12.02 & 24.00 & 24.03 & 24.03 \\
\hline 12.00 & 12.01 & 12.02 & 30.00 & 29.97 & 30.00 \\
\hline 16.00 & 15.95 & 15.94 & 6.00 & 6.04 & 6.01 \\
\hline 16.00 & 15.95 & 15.94 & 12.00 & 12.02 & 12.01 \\
\hline 16.00 & 15.94 & 15.94 & 18.00 & 17.95 & 17.95 \\
\hline 16.00 & 15.93 & 15.94 & 24.00 & 24.01 & 24.03 \\
\hline 16.00 & 15.92 & 15.94 & 30.00 & 29.96 & 30.00 \\
\hline 20.00 & 20.03 & 20.03 & 6.00 & 6.02 & 6.01 \\
\hline 20.00 & 20.03 & 20.03 & 12.00 & 12.00 & 12.01 \\
\hline 20.00 & 20.02 & 20.03 & 18.00 & 17.93 & 17.95 \\
\hline 20.00 & 20.01 & 20.03 & 24.00 & 23.99 & 24.03 \\
\hline 20.00 & 20.00 & 20.03 & 30.00 & 29.94 & 30.00 \\
\hline
\end{tabular}

Table 2: Composition of Validation (Prediction Set) For PLS and PCR Methods

\begin{tabular}{|c|c|c|c|c|c|}
\hline \multicolumn{3}{|c|}{ Rabeprazole sodium } & \multicolumn{3}{|c|}{ Domperidone maleate } \\
\hline \multirow{2}{*}{$\begin{array}{c}\text { Reference } \\
\mu \mathrm{g} / \mathrm{ml}\end{array}$} & \multicolumn{2}{|c|}{ Predicted $\mu \mathrm{g} / \mathrm{ml}$} & \multirow{2}{*}{$\begin{array}{c}\text { Reference } \\
\mu \mathrm{g} / \mathrm{ml}\end{array}$} & \multicolumn{2}{|c|}{ Predicted $\mu \mathrm{g} / \mathrm{ml}$} \\
\hline & PLS & PCR & & PLS & PCR \\
\hline 6 & 6.07 & 6.05 & 9.00 & 8.98 & 8.92 \\
\hline 6 & 6.07 & 6.05 & 15.00 & 15.19 & 15.14 \\
\hline 6 & 6.06 & 6.05 & 21.00 & 21.09 & 21.06 \\
\hline 10 & 9.97 & 9.95 & 9.00 & 8.96 & 8.92 \\
\hline 10 & 9.96 & 9.95 & 15.00 & 15.17 & 15.14 \\
\hline 10 & 9.95 & 9.95 & 21.00 & 21.07 & 21.06 \\
\hline 14 & 14.05 & 14.03 & 9.00 & 8.95 & 8.92 \\
\hline 14 & 14.04 & 14.03 & 15.00 & 15.15 & 15.14 \\
\hline 14 & 14.03 & 14.03 & 21.00 & 21.06 & 21.06 \\
\hline
\end{tabular}

Table 3: Summary of statistics in PLS and PCR methods for Rabeprazole sodium and Domperidone maleate in the mixture

\begin{tabular}{|c|c|c|c|c|c|c|c|c|c|c|}
\hline \multirow{2}{*}{ Drug } & \multicolumn{2}{|c|}{ Rmsep } & \multicolumn{2}{c|}{ Rmsec } & \multicolumn{2}{c|}{$\mathbf{R}^{2}$} & \multicolumn{2}{|c|}{ Intercet } & \multicolumn{2}{c|}{ Slope } \\
\cline { 2 - 11 } & PLS & PCR & PLS & PCR & PLS & PCR & PLS & PCR & PLS & PCR \\
\hline Rabe & 0.0510 & 0.0459 & 0.0349 & 0.0312 & 0.9999 & 0.9999 & 0.0274 & 0.0036 & 0.9981 & 0.9999 \\
\hline Dom & 0.1096 & 0.1010 & 0.0450 & 0.0270 & 0.9999 & 0.9999 & 0.0627 & 0.0017 & 0.9971 & 0.9999 \\
\hline
\end{tabular}

Rabe- rabeprazole sodium, Dom- Domperidone maleate, RMSEP-Root mean square error of prediction, RMSEC-Root mean square error of calibration and $\mathrm{r}^{2-}$ Correlation coefficient

Table 4: Analysis of Tablet Formulation (Assay)

\begin{tabular}{|c|c|c|c|}
\hline Formulation & Label claim & PLS mg/tab found & PCR mg/tab found* \\
\hline \multirow{2}{*}{ RAPEED -D } & Rabe $20 \mathrm{mg}$ & 20.09 & 20.08 \\
\cline { 2 - 4 } & Dom $30 \mathrm{mg}$ & 30.0 & 29.98 \\
\hline
\end{tabular}

*Each value is a mean of six readings 
Vijayageetha Ragupathy et al. Int. Res. J. Pharm. 2013, 4 (6)

Table 5: Precision Data

\begin{tabular}{|c|c|c|c|c|c|c|c|c|}
\hline \multirow{2}{*}{ S. No. } & \multicolumn{4}{|c|}{ System precision } & \multicolumn{3}{c|}{ Method precision } \\
\cline { 2 - 9 } & \multicolumn{2}{|c|}{$\begin{array}{c}\text { Rabeprazole } \\
\text { sodium }\end{array}$} & \multicolumn{2}{c|}{$\begin{array}{c}\text { Domperidone } \\
\text { maleate }\end{array}$} & \multicolumn{2}{c|}{$\begin{array}{c}\text { Rabeprazole } \\
\text { sodium }\end{array}$} & \multicolumn{2}{c|}{$\begin{array}{c}\text { Domperidone } \\
\text { maleate }\end{array}$} \\
\cline { 2 - 9 } & PLS & PCR & PLS & PCR & $\begin{array}{c}\text { PLS \% } \\
\text { purity }\end{array}$ & $\begin{array}{c}\text { PCR \% } \\
\text { purity }\end{array}$ & $\begin{array}{c}\text { PLS \% } \\
\text { purity }\end{array}$ & $\begin{array}{c}\text { PCR\% } \\
\text { purity }\end{array}$ \\
\hline 1. & 12.03 & 12.03 & 17.97 & 17.96 & 100.62 & 100.58 & 100.17 & 100.11 \\
\hline 2. & 12.01 & 12.00 & 17.93 & 17.92 & 100.33 & 100.29 & 99.89 & 99.82 \\
\hline 3. & 12.03 & 12.03 & 17.96 & 17.95 & 100.56 & 100.52 & 100.11 & 100.05 \\
\hline 4. & 12.05 & 12.05 & 18.00 & 17.99 & 100.56 & 100.52 & 100.11 & 100.05 \\
\hline 5. & 12.03 & 12.03 & 17.97 & 17.96 & 100.30 & 100.26 & 99.85 & 99.79 \\
\hline 6. & 12.05 & 12.05 & 18.00 & 17.99 & 100.24 & 100.20 & 99.80 & 99.73 \\
\hline AVG & 12.03 & 12.03 & 18.02 & 18.00 & 100.44 & 100.40 & 99.99 & 99.93 \\
\hline S.D & 0.0175 & 0.0176 & 0.03 & 0.03 & 0.1626 & 0.1632 & 0.1619 & 0.1629 \\
\hline \%RSD & 0.1462 & 0.1468 & 0.15 & 0.15 & 0.1619 & 0.1626 & 0.1619 & 0.1630 \\
\hline
\end{tabular}

Table 6: Recovery Studies

\begin{tabular}{|c|c|c|c|c|c|c|c|c|c|c|}
\hline \multirow{2}{*}{$\begin{array}{c}\text { \% of } \\
\text { Target }\end{array}$} & \multicolumn{5}{|c|}{ Rabeprazole sodium } & \multicolumn{5}{|c|}{ Domperidone maleate } \\
\hline & \multicolumn{3}{|c|}{ PLS } & \multicolumn{2}{|c|}{ PCR } & \multicolumn{3}{|c|}{ PLS } & \multicolumn{2}{|c|}{ PCR } \\
\hline \multirow{7}{*}{80} & $\begin{array}{c}\text { Added } \\
\text { mg }\end{array}$ & $\begin{array}{c}\text { Found } \\
\text { mg }\end{array}$ & $\begin{array}{c}\% \\
\text { Recovery }\end{array}$ & $\begin{array}{c}\text { Found } \\
\text { mg }\end{array}$ & $\begin{array}{c}\% \\
\text { Recovery }\end{array}$ & $\begin{array}{c}\text { Added } \\
\text { mg }\end{array}$ & $\begin{array}{c}\text { Found } \\
\text { mg }\end{array}$ & $\begin{array}{c}\% \\
\text { Recovery }\end{array}$ & $\begin{array}{c}\text { Found } \\
\text { mg }\end{array}$ & $\begin{array}{c}\% \\
\text { Recovery }\end{array}$ \\
\hline & 9.6 & 9.61 & 100.14 & 9.60 & 100.00 & 14.40 & 14.36 & 99.70 & 14.32 & 99.47 \\
\hline & 9.6 & 9.62 & 100.25 & 9.61 & 100.11 & 14.40 & 14.37 & 99.81 & 14.34 & 99.59 \\
\hline & 9.6 & 9.57 & 99.64 & 9.55 & 99.49 & 14.40 & 14.28 & 99.20 & 14.25 & 98.97 \\
\hline & \multirow{3}{*}{$\begin{array}{l}\text { Mean } \\
\text { SD } \\
\% \text { RSD }\end{array}$} & 9.60 & 100.01 & 9.59 & 99.87 & \multirow{3}{*}{$\begin{array}{c}\text { Mean } \\
\text { SD } \\
\% \text { RSD }\end{array}$} & 14.33 & 99.57 & 14.30 & 99.34 \\
\hline & & 0.03 & 0.33 & 0.03 & 0.33 & & 0.0493 & 0.33 & 0.047 & 0.33 \\
\hline & & 0.33 & 0.33 & 0.33 & 0.33 & & 0.3440 & 0.33 & 0.33 & 0.33 \\
\hline \multirow[t]{6}{*}{100} & 12 & 11.98 & 99.87 & 11.98 & 99.83 & 18.00 & 17.90 & 99.43 & 17.88 & 99.36 \\
\hline & 12 & 12.02 & 100.13 & 12.01 & 100.09 & 18.00 & 17.94 & 99.69 & 17.93 & 99.62 \\
\hline & 12 & 11.95 & 99.62 & 11.95 & 99.58 & 18.00 & 17.85 & 99.18 & 17.84 & 99.11 \\
\hline & \multirow{3}{*}{$\begin{array}{c}\text { Mean } \\
\text { SD } \\
\% \text { RSD }\end{array}$} & 11.98 & 99.87 & 11.98 & 99.83 & \multirow{3}{*}{$\begin{array}{c}\text { Mean } \\
\text { SD } \\
\% \text { RSD }\end{array}$} & 17.89 & 99.43 & 17.88 & 99.36 \\
\hline & & 0.03 & 0.26 & 0.03 & 0.26 & & 0.0450 & 0.25 & 0.045 & 0.26 \\
\hline & & 0.26 & 0.26 & 0.26 & 0.26 & & 0.251 & 0.26 & 0.252 & 0.26 \\
\hline \multirow[t]{6}{*}{120} & 14.4 & 14.46 & 100.42 & 14.46 & 100.44 & 21.60 & 21.59 & 99.97 & 21.60 & 100.01 \\
\hline & 14.4 & 14.41 & 100.09 & 14.42 & 100.12 & 21.60 & 21.52 & 99.65 & 21.53 & 99.69 \\
\hline & 14.4 & 14.39 & 99.92 & 14.39 & 99.95 & 21.60 & 21.49 & 99.48 & 21.50 & 99.52 \\
\hline & Mean & 14.42 & 100.14 & 14.42 & 100.17 & Mean & 21.53 & 99.70 & 21.54 & 99.74 \\
\hline & \multirow{2}{*}{$\begin{array}{c}\mathrm{SD} \\
\% \mathrm{RSD}\end{array}$} & 0.04 & 0.25 & 0.04 & 0.25 & \multirow{2}{*}{$\begin{array}{c}\mathrm{SD} \\
\% \mathrm{RSD}\end{array}$} & 0.0513 & 0.25 & 0.015 & 0.25 \\
\hline & & 0.25 & 0.25 & 0.25 & 0.25 & & 0.238 & 0.25 & 0.238 & 0.25 \\
\hline
\end{tabular}

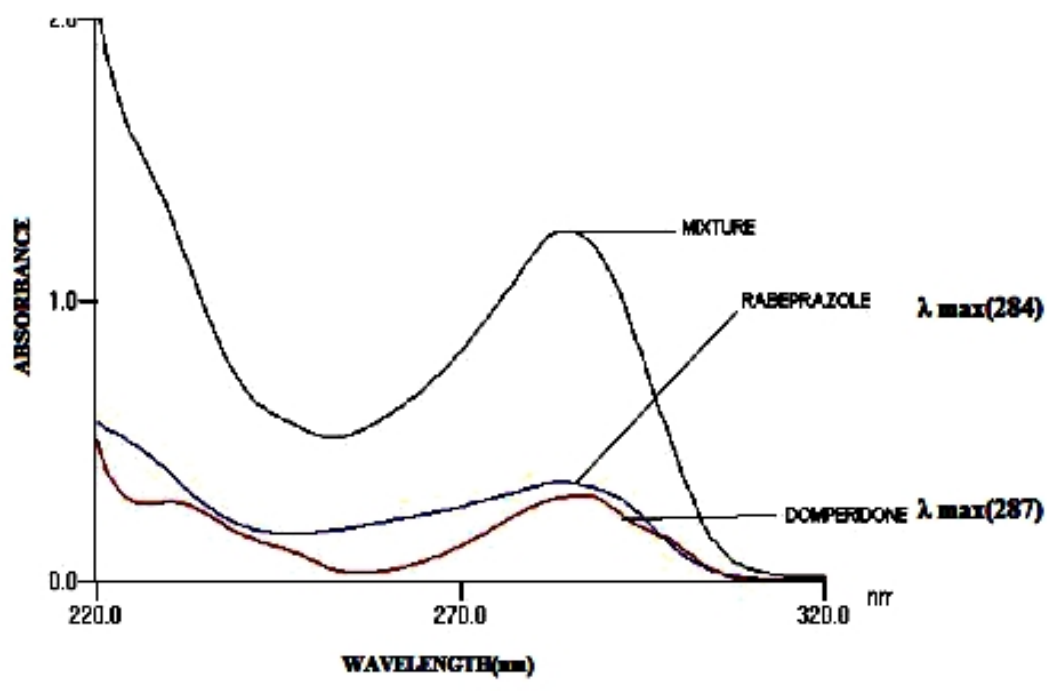

Figure 1: Overlaid Spectra of Rabeprazole sodium and Domperidone maleate 


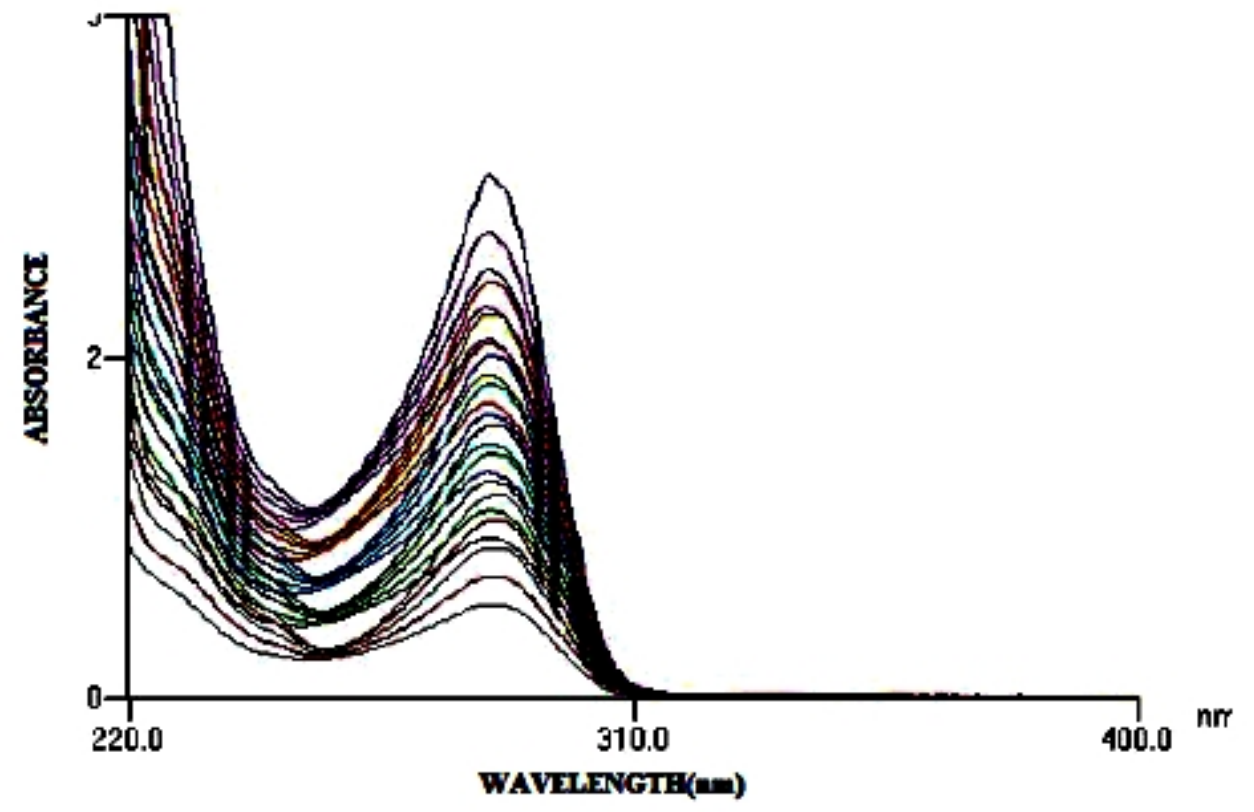

Figure 2: Calibration Spectra of Rabeprazole sodium and Domperidone maleate

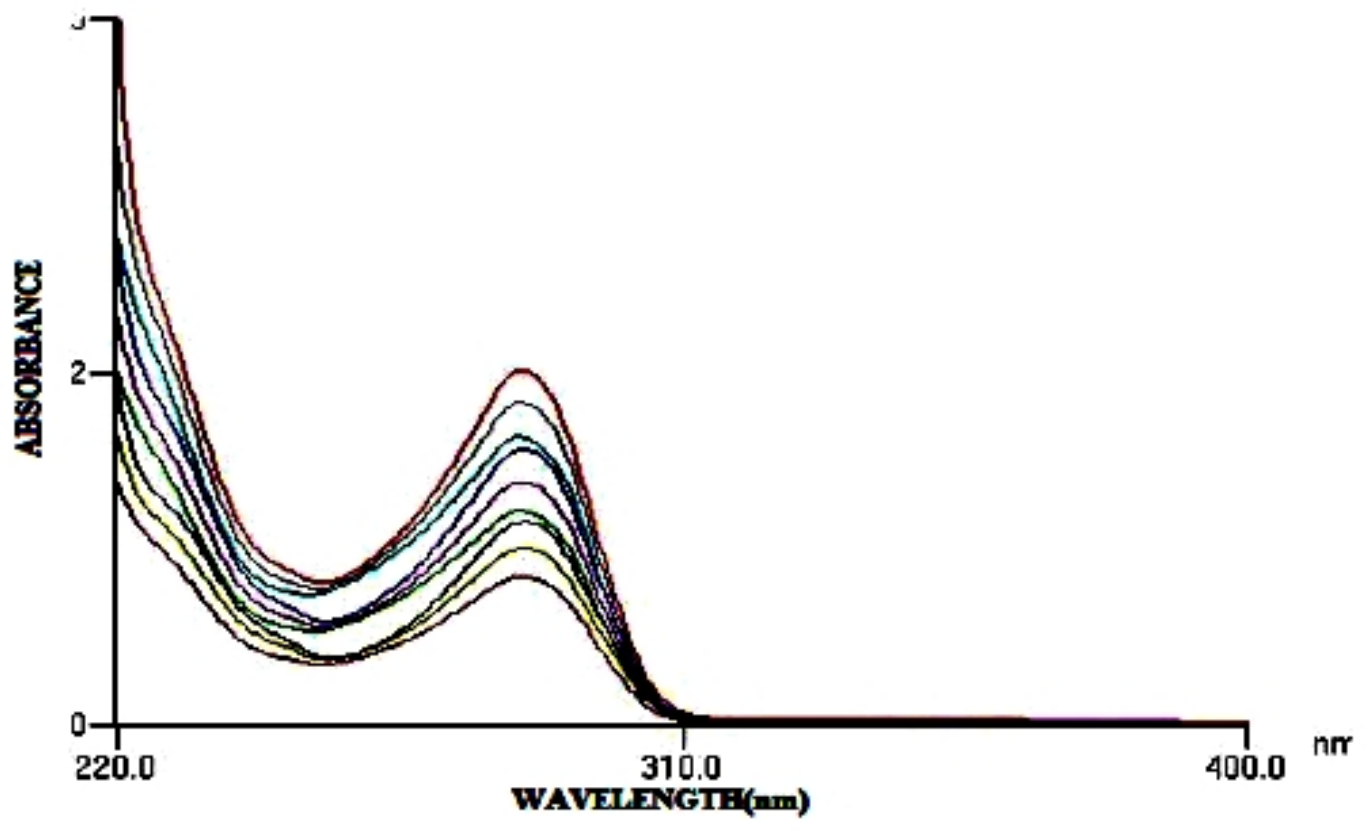

Figure 3: Prediction Spectra of Rabeprazole sodium and Domperidone maleate 


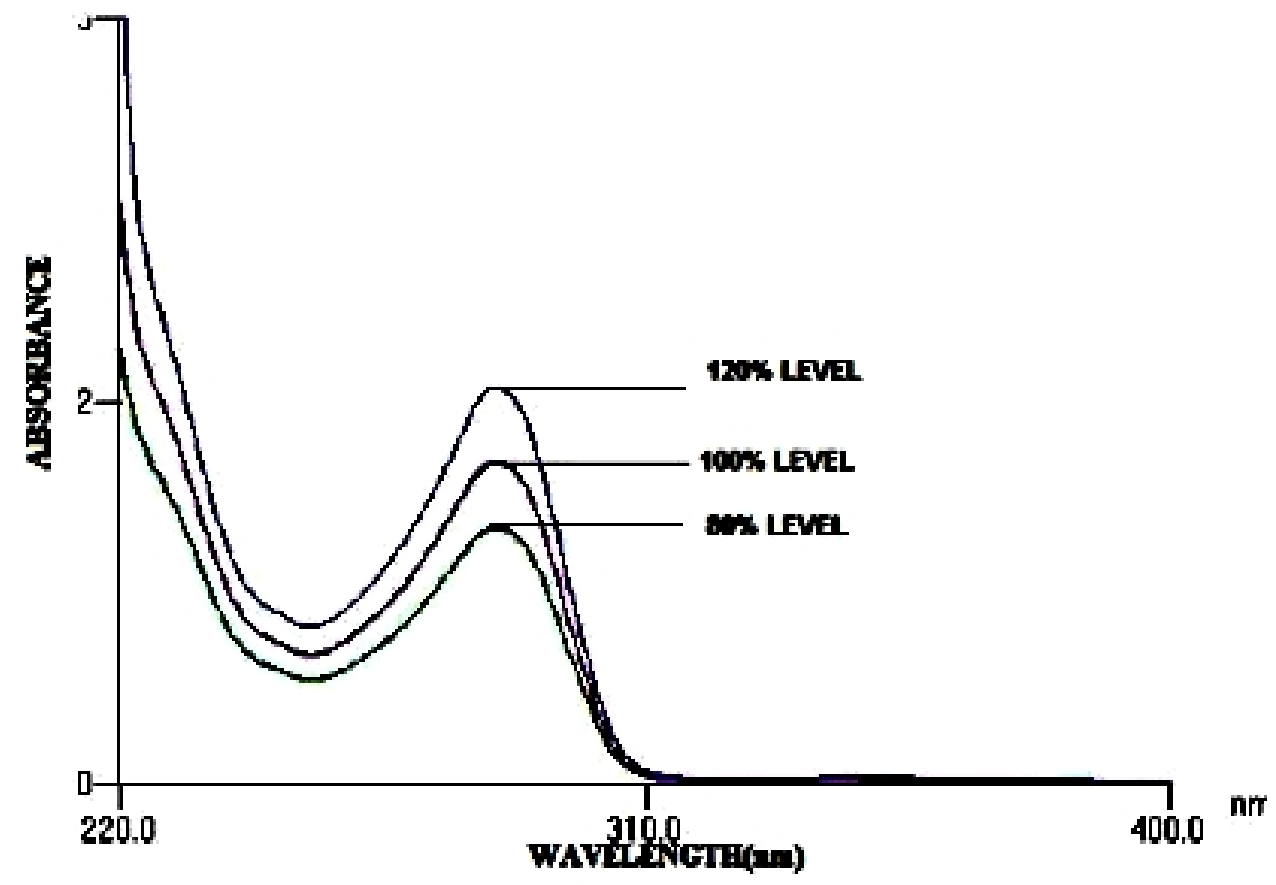

Figure 4: Recovery Spectra of Rabeprazole sodium and Domperidone maleate

Two sets of standard solutions were prepared, the calibration set contained 25 standard solutions and the prediction set contained 9 standard solutions. To a series of $10 \mathrm{ml}$ volumetric flasks, aliquots of Rabeprazole sodium and Domperidone maleate solutions, containing appropriate amount of these drugs in the range of calibrations, were added and then the solutions were diluted to $10 \mathrm{ml}$ with methanol. UV spectra of the mixtures were recorded in the wavelength range 221-309nm versus a solvent blank, and digitized absorbance was sampled at $1 \mathrm{~nm}$ intervals. All the solutions were prepared freshly and were protected from light.

\section{Sample preparations}

Twenty capsules were accurately weighed and powdered in a mortar. An amount of the powder equivalent was weighed and dissolved in methanol in $100 \mathrm{ml}$ calibrated flasks. $20 \mathrm{ml}$ of methanol was added and ultra sonicated for 10 minutes and the volume was made up to $100 \mathrm{ml}$ with methanol and shake well. Then, the solution was filtered through what man filter paper No. 4land the residue was washed three times with $10 \mathrm{ml}$ of solvent and then the volume was completed to $100 \mathrm{ml}$ with methanol. The resulting solution was diluted to $1: 1.5$ in a $100 \mathrm{ml}$ calibrated flasks. Both techniques were applied to the prepared sample solutions.

\section{RESULTS AND DISCUSSIONS}

The absorption spectra of RABE and DOM solutions in methanol recorded between 221-309nm were shown in Figure 1. The two drugs show an overlap in their absorption.

\section{Experimental design of sample sets}

Calibration and test sets for two component systems were designed according to factorial principle five-level factorial design was used to produce a calibration set (Training step) of 25 samples. Calibration spectra are shown in Figure 2. A three-level set was derived to produce a prediction set (Validation step) of nine samples. Prediction spectra are shown in Figure 3. The compositions of the used calibration and Validation sets are summarized in Tables 1 and 2 respectively.

\section{Selection of optimum number of factors and the spectral region}

The most commonly employed validation criterion is to divide the dataset into two subsets, a calibration set and a validation set. The calibration model is calculated using the calibration set. Then, the root mean square errors of calibration and validation, RMSEC - root mean square error of calibration and RMSEP- root mean square error of prediction, are calculated using the calibration model under investigation to predict the samples in the calibration set and validation set, respectively. The results are presented in Table 3.

\section{Market Sample Analysis (Assay)}

The proposed PLS and PCR methods were applied to the simultaneous determination of RABE and DOM in commercial capsules. Determination of six replicates was made. Satisfactory results were obtained for each drug in good agreement with the label claims. The results are presented in Table 4.

\section{Precision}

The method was found to be precise with six sample preparations for the quantification of RABE and DOM. The precision and intermediate precision variations were calculated in terms of relative standard deviation and the results were found to be less than $2.0 \%$ and the results are presented in Table 5.

\section{Recovery Studies}

To check the validity of the proposed methods, recovery studies were carried out by addition of the standard to the pre-analyzed formulation. (Standard addition technique) 
Recovery spectra are shown in Figure 4 and the results are presented in Table 6.

\section{CONCLUSIONS}

The most striking features of chemometric methods are its simplicity and rapidity without requiring time-consuming sample preparation. Chemometric calibration techniques in spectral analysis are widely used in quality control of drugs in mixtures and multi- component pharmaceutical formulations with overlapping spectra, as separation procedures in the drug determinations are not required. A comparative study of the use of PLS and PCR for the simultaneous spectrophotometric determination of Rabeprazole sodium and Domperidone maleate has been accomplished. High percentage of recovery shows that the methods are free from interference of the excipients used in the commercial formulation. Results also showed that the developed methods can be applied to a routine analysis, quality control of mixtures and commercial preparations containing these drugs.

\section{ACKNOWLEDGEMENT}

The author thanks our management of C.L Baid Metha college of Pharmacy and Ideal Analytical Research Institution, Pondicherry, India for their Instrumental support of this investigation.

\section{REFERENCES}

1. Riley MR, Kastrup EK, Hebel SK. Facts and Comparisons, $55^{\text {th }}$ ed. Missouri: USA; 2001. p. 1167

2. MF Francis, L Lavoie, FM Winnik. Solubilization of cyclosporine A in dextran-g-polyethylene glycol-alkyl ether polymeric micelles. Eur J Pharm Bio pharm 2003; 56: 337-46. http://dx.doi.org/10.1016/S09396411(03)00111-5

3. European Pharmacopoeia; Council of Europe Strasburg; $3^{\text {rd }}$ ed; 1997. p. 778-80

4. British Pharmacopoeia, HMSO publication, London: U.K; 2002. p. 40

5. Patel AH, Patel JK, Patel KN, Rajput GC, Rajgor NB. Development and validation of derivative spectrophotometric method for simultaneous estimation of Domperidone and Rabeprazole sodium in bulk and dosage forms. Int J Pharm Biol Res 2010; 1(1): 1-5.

6. Nesrin K Ramadan, Heba M Mohamed, Azza A Moustafa. Simultaneous determination of Rabeprazole sodium and Domperidone. J Appl Pharm Sci 2011; 1(9): 73-80.
7. Dobaria NB, Vadia NH, Rajput SJ. Simultaneous spectrophotometric estimation of Rabeprazole sodium and Domperidone maleate in their combined pharmaceutical dosage form. Int J ChemTech Res 2009; 1(4): $1162-6$.

8. Shweta S Sabnisa, Nilesh D Dhavalea, Vijay Y Jadhava, Santosh R Tambeb, Santosh V Gandhi. A spectrophotometric simultaneous determination of Rabeprazole sodium and Domperidone in combined tablet dosage form. Eurasian J Anal Chem 2008; 3(2): 236-44.

9. Baldha RG, Patel Vandana B, Mayank Bapna. Simultaneous spectrophotometric estimation of Rabeprazole sodium and Domperidone in combined dosage forms. Int J PharmTech Res 2010; 2(2): 1563-8.

10. Kalirajan R, Anandarajagopal K, Seena Mary Mathew, Gowramma B, Jubie S, Suresh B. Simultaneous determination of Rabeprazole and Domperidone in dosage forms by RP-HPLC. Rasayan J Chem 2008; 1(2): $232-5$.

11. Sabnis SS, Dnvandev DN, Jadhav VY, Gandhi SVV. Column reversedphase high-performance liquid chromatographic method for determination of Rabeprazole sodium and Domperidone in combined tablet dosage form. JAOAC Int 2008; 91(2): 344-8. PMid:18476346

12. Bhavesh H Patel, Madhabhai M Patel, Jignesh R Patel, Bhanubhai $N$ Suhagia. HPLC analysis for simultaneous determination of Rabeprazole and Domperidone in pharmaceutical formulation. J Liq Chroma Rela Tech 2007; 30 (3): 7439-45.

13. Chitlange SS, Mulla AI, Pawbake GR, Wankhede SB. Stabilityindicating TLC-densitometric method for estimation of Dexrabeprazole and Domperidone in pharmaceutical dosage form.Prep Biochem Biotechnol 2010;40(4):337-46. http://dx.doi.org/10.1080/10826 068.2010.525410 PMid:21108137

14. Patel Bhavesh H, Suhagia Bhanubhai N, Patel Madhabhai M, Patel Jignesh R. HPTLC determination of Rabeprazole and Domperidone in capsules and its validation. J Chromatogr Sci 2008; 46(4): 304-7. http:/ /dx.doi.org/10.1093/chromsci/46.4.304 PMid:18402720

15. Gandhi SV, Khan SI, Jadhav RT, Jadhav SS, Jadhav GA. Highperformance thin-layer chromatographic determination of Rabeprazole sodium and Domperidone in combined dosage form. J AOAC Int 2009; 92(4): 1064-7. PMid: 19714973

16. Vigneau E, Devaux MF, Qannari EM, Robert P. Principal component regression, ridge regression and ridge principal component regression in spectroscopy calibration. J Chemom 1997; 11: 239-49. http://dx.doi.org /10.1002/(SICI)1099-128X(199705)11:3<239::AIDCEM470>3.0.CO;2-A

17. Brereton R. Chemometrics, Data Analysis for the Laboratory and Chemical Plant, Wiley, Chichester; 2003. PMCid:340019

Cite this article as:

Vijayageetha Ragupathy, Shantha Arcot. Simultaneous spectrophotometric determination of Rabeprazole sodium and Domperidone maleate in capsules by chemometric methods. Int. Res. J. Pharm. 2013; 4(6):72-77 